\title{
Democratization
}

\section{The reform-security dilemma in democratic transitions: the Turkish experience as model?}

\section{Ersel Aydinli}

To cite this article: Ersel Aydinli (2013) The reform-security dilemma in democratic transitions: the Turkish experience as model?, Democratization, 20:6, 1144-1164, DOI: 10.1080/13510347.2013.811194

To link to this article: https://doi.org/10.1080/13510347.2013.811194

曲 Published online: 25 Jun 2013.

Submit your article to this journal ๘

Џll Article views: 800

4 Citing articles: 1 View citing articles 


\title{
The reform-security dilemma in democratic transitions: the Turkish experience as model?
}

\author{
Ersel Aydinli* \\ Department of International Relations, Bilkent University, Ankara, Turkey
}

(Received 20 November 2011; final version received 6 February 2012)

\begin{abstract}
In considering the future of budding Middle Eastern democracies, past experience and scholarship show that a possible outcome for even the most "successful" ones is some form of imperfect democracy. Based within the literature on democratic transitions and hybrid regimes, this article explores possible factors leading to such outcomes. It focuses in particular on reform/ security dilemmas, and the resulting evolution of dual state structures, in which an unelected and often authoritarian state establishment coexists with democratic institutions and practices, for example, in countries like Russia, Iran, or Pakistan. Much of the literature views such duality as an impasse, and thus considers these countries as trapped within this "hybridness" discouraging news both for currently defined "hybrid regimes" and for countries like Egypt and Tunisia, which are now launching democratization processes. To better understand the nature and evolution of such regimes, this article looks at the case of Turkey, first tracing the rise and consolidation of the Turkish inner state, generally equated with the Turkish armed forces. It then looks at the apparent diminishing and integration of the inner state through pacts and coalitions among both civilian and military elements, and calls into question whether the pessimistic view of permanent illiberalness is inevitable.
\end{abstract}

Keywords: reform security; Turkey; democratization; transitions; hybrid regimes; Middle East

\section{Introduction}

The ongoing revolutions in the Middle East have resparked debate over the compatibility of Islam and democracy. As a contender for the position of a "model" democracy in the Muslim world, Turkey, despite its problems, has held the lead for several years. The Islamist Justice and Development (AK) party is seen by many as an example of a successful merging of Islam and democratic practice, leading to its labelling as a model by past and present Western leaders, ${ }^{1}$ as well as by the popular media and in scholarly literature. These accounts have ranged from positive descriptions of Turkey's exemplifying potential ${ }^{2}$ to the more cautious ${ }^{3}$; with others arguing that Turkey's unique history, geographical location, and culture reduce the feasibility of such a role. ${ }^{4}$ Nevertheless, public opinion of

*Email: ersel@bilkent.edu.tr 
Turkey as a model remains popular, most recently among those caught up in the movements of the "Arab Spring". 5

The idea of serving as a model can be considered at two levels: providing an "end result" example of what a Middle Eastern democracy might look like; and providing an example of the process by which a country might achieve a transition from a non-democratic, authoritarian regime to a democratic one. While the end result picture is welcomed by publics hungry for optimistic news - it worked there, it can work here - it is actually the process which is obviously of greater importance. Perhaps the only thing that is clear about the future of transitioning countries like Egypt or Tunisia is that they are embarking on a long journey, the stages of which will inevitably include ups and downs. What types of setbacks and stumbling blocks might they face and what might their sources be? Will setbacks necessarily mean the failure of a transition process? While recognizing the uniqueness of every country's individual history, leadership, context, and culture, a look at the example of Turkey, not only in its current "end result" but in the very tumultuous process via which it reached its current stage of political liberalization, can perhaps provide some insights for countries embarking on their own transition processes and help lead to recommendations for overcoming the reform/security dilemma in the long run.

\section{The reform/security dilemma}

As acknowledged above, transitions from authoritarian regimes to democratic ones do not occur overnight, nor is the process always a linear one. Democratic transitions almost certainly face challenges, sometimes resulting in outright reversals, or perhaps culminating in something that does not exactly resemble a liberal democracy. Thus we see many countries around the world appearing to stagnate at a point between authoritarianism and democracy, ${ }^{6}$ and the literature is replete with reports on the persistence of so-called hybrid regimes, ${ }^{7}$ semi-democracies, ${ }^{8}$ illiberal democracies, ${ }^{9}$ imitation democracies, ${ }^{10}$ pseudo-democracies, ${ }^{11}$ electoral democracies, ${ }^{12}$ praetorian states, ${ }^{13}$ military democracies ${ }^{14}$ sovereign democracies, ${ }^{15}$ or the all-encompassing democracies with adjectives. ${ }^{16}$ Underlying all of these terms is the understanding that the existing "democracy" is somehow limited; it has been unable to transform into a fully consolidated liberal democracy. This limitation may range from cases of countries in which there are elections held but no true sense of civil liberties, to countries that have advanced significantly along the path of democratization and liberalization but still maintain some degree of unaccountable authoritarian power source in their governance, for example, a powerful monarch or a military that is not entirely under civilian control. Regardless of the individual details, such countries all seem to reside in the political "gray zone" exemplifying the "end-of-the-transition-paradigm" argument. ${ }^{17}$

A common thread among these cases, and an issue that will almost certainly be relevant for transitioning Middle Eastern countries, is often the idea that the cause 
for this limited democracy is a rationale of needing to maintain security. Whether due to existing security challenges or to fears that emerge directly from the political opening-up process itself, not only the leading elites but even the societies of these countries may adopt an understanding that a safety belt or guarantor for the liberalization process is necessary. ${ }^{18}$ Therein lies a dilemma: such a safety belt must be a security providing mechanism, and therefore must include strong security institutionalization - a process that is almost inevitably illiberal in nature, since it represents a type of authoritative, centralization of power at a time when political decentralization is meant to be on the rise.

While the transitions literature obviously carries the basic understanding that successful transitions mean the removal of the authoritarian regime, it also includes the idea of pacts, which allows for the possibility of a role for at least some part of the authoritarian power in the democratization process - a crucial point when considering the regime/security dilemma, and the arguable need for a guarantor in the process. Indeed, one of the basic tenets of the transition literature is that a primary causal variable during transitions is elite bargaining, and in particular, the strategic interaction between leaders of the former regime and representatives of the opposition forces. Basically, O'Donnell and Schmitter wrote that authoritarian regimes may be willing to enter into a power-sharing agreement or pact with opposition forces when key elements of the ruling apparatus decide that the status quo is unsustainable and that the regime is going to require some form of "electoral legitimation". ${ }^{19}$ The key to a successful move for transition is linked to divisions in the authoritarian regime itself, generally between hardliners and softliners in the military. The argument runs that in the face of public protests against the authoritarian leadership, hardliners argue that the crisis does not warrant the risks of liberalization, while softliners fear that barring the granting of some liberal rights/electoral liberalization, they will be removed from power. It is these softliners who may become part of a "dissenting alliance" in support of transition - the implied magnanimity of which has been questioned, though not the resulting pacts themselves. ${ }^{20}$

Given the evidence from democratization processes in recent decades however, the key question with respect to pacts may be whether so-called "pacted transitions" are just another way of explaining the evolution of stagnant limited democracies and hybrid regimes. Even a leading transitions scholar, reflecting on the past quarter-century of scholarship and experience, has noted that there may be a tendency for pacted transitions to "lock in" existing privileges for people. ${ }^{21}$

On the other hand, some recent works have questioned the idea that democratization should immediately aim at fully eradicating or even greatly weakening the existing authoritarian powers. In Asia, a comparison of the progress of democratization in Malaysia, Singapore, and Indonesia suggests that a more controlled and secure - but less democratic - transition process in Singapore has bred a context in which liberal democratic values are now slowly taking hold, ${ }^{22}$ and from the side of democracy promotion, some cautious recognition has been given to the potential of "liberal authoritarian" responses. ${ }^{23}$ In Africa, although elections alone have 
been rightly questioned as an accurate measure of democratization, ${ }^{24}$ a quantitative study of democratizing countries has still gone against the stagnation argument by showing that the more times elections are held, even if interspersed by periods of reversal to authoritarianism, the lower the chances become for future military intervention, ${ }^{25}$ and a comparative case study has presented the idea that a democracy with authoritarian roots can be successful. ${ }^{26}$ In the Middle East, it has been argued that democratization through pacts with the power-holding elites is the best way to guarantee gradual acceptance of liberal democratic values. ${ }^{27}$

Which brings us to the crux of the reform/security dilemma: Will guarantors of security inevitably remain as constant blockages to a full liberalization process? In other words, does the reform/security dilemma necessarily represent an impasse? One way of exploring such questions is to consider the case of Turkey, a country that has long been exposed to the dilemma of balancing demands for both liberal reform and security, ${ }^{28}$ and which, despite common references to it as a model, has with even greater frequency been viewed as an example of an imperfect, limited democracy. After more than 50 years of multiparty politics and the transformations it has made in order to meet European Union (EU) membership accession criteria, Turkey has had trouble shaking the image that it is run by the not-so-invisible Turkish army - an unaccountable, "inner-state" structure. This idea is evident both in the literature ${ }^{29}$ and in popular belief internationally. ${ }^{30}$ In recent years, however, the country seems to be witnessing some success in moving beyond the reform/security dilemma, suggesting the need to look more carefully at the longitudinal process of this country's democratic transition. Because of Turkey's long history of struggling with the dilemma of reconciling reform and security, its experience can provide more than just a snapshot of such an inner state structure; it allows for a look at its rises and declines, its potentially evolving functions, and changes in its relations with the society and civilian leaders.

The following sections explore the role of Turkey's inner state in the country's democratization process by asking: What exactly is the inner state in Turkey and why did it come to exist? What role has Turkey's inner state played in the country's overall political liberalization process? Finally, what can a longitudinal look at the decades of interplay between the Turkish inner state and the forces of democratic transformation teach us about today's democracies with adjectives, the possible futures of the newly transforming countries of the "Arab Spring", and about the potential for overcoming the reform/security dilemma? The following sections explore these questions by tracing the Turkish experience throughout the twentieth and early twenty-first centuries, from the earliest efforts for liberalization through to the current day.

\section{Understanding Turkey's inner state}

In looking at the various entities that have at times been reportedly connected with or determined to constitute Turkey's "inner" or "deep state", a common bond among them tends to be their intent on maintaining the status quo of the overall 
existing governance structure. The justification for their existence is generally that the politically elected government has lost control, and if efforts outside of regular governmental practice are not made, the whole state together with the nation will collapse. These alternative power sources claim therefore to be seeking to secure the state's continuity in the face of revolutionary political experiments gone out of control. Institutionally, the Turkish inner state can be equated with the Turkish army. However, since the backdrop of the inner state is based on a broad ideological and psychological sentiment of fear of collapse, "inner statehood" extends well beyond the army, into parts of the state bureaucracy and even into the society itself. It includes a variety of actors, large (for example, the secular judiciary) and small (for example, individual newspaper columnists), legitimate (for example, the National Security Council) or not (for example, groups such as the Kuvvacilar ${ }^{31}$ ), those particularly organized for this vanguard mission to those just offering their services and support on an ad hoc basis.

In this article, the term "inner state" is used when referring to this broader "coalition" and ideological convergence. The military is named directly when referring to that institution in particular.

Still unanswered, however, is the question of whether this inner state and in particular its core of the Turkish military is a static entity, an indication of a firmly entrenched imperfect democracy, or whether it can change - or be changed over time to gradually and safely allow the overall Turkish governance system to become a truly liberal democratic one. Leading scholarship on the overall Turkish state structure has generally held the conviction that because of a continuous strong internal security threat perception and resulting securitization process (with its openness to an over-prioritization of national security), the Turkish military maintains its position as an autonomous and isolated part of a therefore relatively static Turkish state, ${ }^{32}$ and even recent works on the Turkish military are often disinclined to see genuine change in the military's autonomous position. ${ }^{33}$ Once having been identified as such, there naturally remained little incentive to delve further into this static inner state structure. ${ }^{34}$ Moreover, since access to the "black box" of the inner state was also very restricted, research on the subject was further stalled. Most scholars turned their attention instead to the more dynamic, open, and relatively newer components of Turkish politics, such as democratic parties and civil society. ${ }^{35}$ These areas of research naturally took on greater importance as issues such as the Kurdish question or the political Islamist challenge took hold in Turkish politics, resulting in still further abandonment of inquiry into the "already resolved" concept of the Turkish inner state establishment.

It is arguable, however, that when we look holistically and longitudinally at the Turkish state and its evolution, the static appearance is rather a reflection of a particular structural balance between the main forces shaping up Turkish statehood, namely the respective forces of security and reform demands and their corresponding manifestation in the duality of inner state and government. What appears as static therefore, may be a reflection of Turkey's historical need to find a working balance between these demands, and thus to insure a relatively safe transformation 
process. If the primary internal process in Turkish governance is a dynamic balancing between reform and security, a tilt towards one direction, even a long-lasting one, does not mean that it can never change. Such a balancing nature also means that once one of the forces is significantly altered, so will be the nature of Turkish statehood.

An overview of the Turkish case seems to reveal that even when political reformation and modernization were accepted by the broad leading elite as a primary goal, the parties involved (various societal elites, the military, and, later on, politicians) did not necessarily have the same understanding and expectation of the outcome or the process of this transformation. For some it might have meant true liberal political reform, for others it might have meant modernization and Westernization. Nevertheless, throughout the process, an overall "pulling and hauling" between proponents of these differing agendas and methods produced a peculiar pattern of illiberal democratization for secure reform. This outcome is independent from the original intentions of all the parties involved, but reveals the evolved form of their combined minimum conditions. Throughout the interactive process the Turkish military has had to accept that they can not hold on to power indefinitely and they can not rule the country from behind the scenes, while the political elite have learned that their power is not limitless and they cannot use democracy to take the country in whatever direction they want - particularly if it contradicts the original principles of the Republic's foundation. Finally, the society has learned that at the end it is a democracy that they want, but not at the risk of overall collapse, and therefore they must resist all kinds of radicalism.

\section{Origins of a security/reform pendulum}

The roots of this balancing between reform and security go back to the strategic choice first made by the Ottoman elite in the nineteenth century to commit the country to modernization.

Adaptation of an irreversible national policy of modernization became the second major force - next to the traditional one of guaranteeing territorial security - of Turkish political modus vivendi. There were three early characteristics of interaction between these two forces.

First, at a time when the Ottoman Empire was in a state of constant territorial contraction, the elite who were in favour of liberal reforms justified their liberalization agenda by claiming it would better protect the state from various security threats. Security, in other words, was seen as the end while modernization was the means. Second, there was at the time (and arguably continues to exist) a fear among the elite of uncontrolled devolution of power. This security-based cautiousness towards political liberalization as a part of modernization was often connected to a concern that liberalization and political reform would empower ordinary citizens, of whom the elite held an inherent mistrust. Third, the very ruling elite that assumed the mission of promoting liberalizing reforms was, ironically, the same group whose primary responsibility it was to protect the country's national security. 
At times of immediate threat, when the two elements clashed, the elite's role as the professional security guardian of the state and the regime prevailed, therefore spelling at least a temporary end to liberalization.

These three characteristics were the starting points in the emergence of a structural pendulum between security and liberalization in the Turkish state. Looking at a model of Turkey's state transformation in response to the prime directive of balancing between these two (see Figure 1), this pendulum stage is represented by figures A and B exerting pressure on the Turkish state. For the most part, the security of the state enjoyed a clear primacy over the liberalization side of the pendulum, resulting in a kind of "reserved" westernization that often contradicted fundamentally with the liberalizing ideals.

While the early part of the twentieth century was marked by much warfare, the mid-1920s saw a return to relative peace, and an increasing push among some in the ruling elite for further liberalization. Most notable of their efforts were two early attempts to introduce multiparty politics. In the face of internal security issues however, such as Kurdish rebellions in the east and the rise of violent opposition to the secular reforms ${ }^{36}$ the more security-minded elite opposed the efforts, arguing that excessive democratic reforms would endanger the regime and the very state itself. Throughout the subsequent securitization process, the attempts for multiparty politics failed. If society was not yet ready to be trusted with democracy, desires for world-standard democratic values would have to be postponed, if not sacrificed, in the name of preventing anarchy and regime insecurity.

\section{From pendulum to bifurcation: a grand compromise}

Throughout the 1930s and early 1940s, the security of the regime and state held primacy in public life, and in the continuing pendulum between security and liberalization. At the end of World War II however, the Turkish state elite opted once again for multiparty politics. In an effort to materialize a deeper integration with the West and therefore a greater sense of security, the state elite realized that a

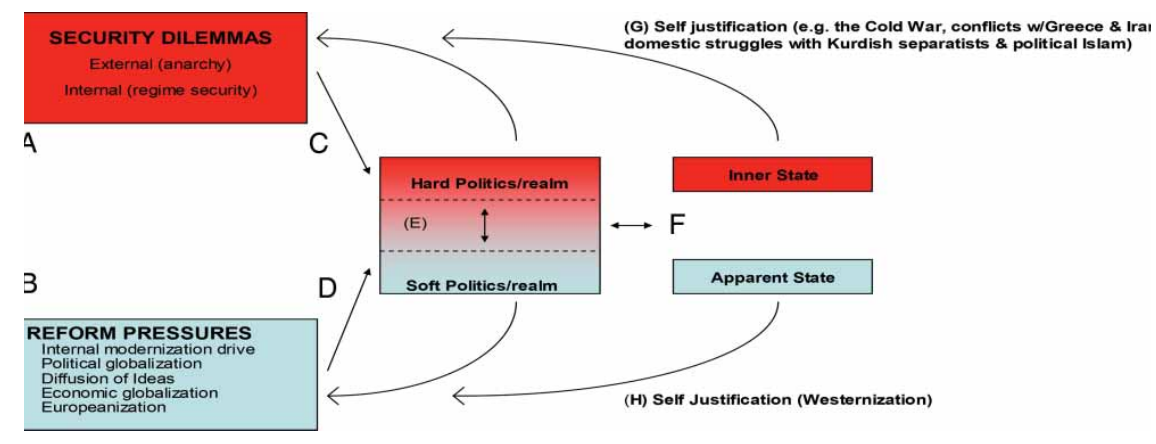

Figure 1. The Turkish inner state model. 
fuller embracing of Western political values and identities would also be required. By emphasizing democracy, the Turkish elite could satisfy the urge to become a part of the "safe" West, but also help to speed up and secure its own modernization project. The result was the establishment in 1946 and ultimate election in 1950 of the Democratic Party.

Fear of the Democratic Party's goal to change the unbalanced power situation between itself and the rest of the political system, which, at the time, was a kind of mixed, embedded body of the state and the single party elite led, ultimately, to the 1960 military coup. What followed would have long-term implications for the maintenance of an "optimal" balance between reform and security. In the wake of the 1960 coup, two main positions emerged among the military on how the nation should be administered: that of the "gradualists", who preferred a quick return to political rule, albeit under a serious level of control by the statist elite and the army; and that of the "absolutists", generally the younger officer class, who felt that the army should stay in power in order to speed up the social and political transformations in the country. The interesting point here was that neither the absolutists nor the gradualists were against further political transformation, but they differed over how quickly, sharply, and "safely" (that is, under how much authoritarian control) that transformation would be managed. Ultimately, the absolutists' ideas were radical and threatening, both to the gradualist military leadership and obviously to the political leaders, and served to force the rest of the politicomilitary actors to come together in a consensus.

\section{Two executions, two syndromes}

With the signing of a compromise protocol in which the politicians agreed, among other things, to support the presidency of the former coup leader, a kind of powersharing among the gradualist state elite was established. Multiparty politics would be allowed to continue, but security demands would be permitted to impose certain restrictions on the political realm when necessary. Lack of obedience to this compromise by the political elite was virtually unthinkable. The vivid image of the hanged Democratic Party leaders, including the former Prime Minister Adnan Menderes, served as a haunting reminder - a kind of Menderes Syndrome - for what could occur if they and their actions were construed as risky and thus served as ammunition for the absolutist elements inside the military to gain strength. These absolutist radical elements within the military then received a lesson of their own however, when, in 1962, a second coup attempt by absolutist forces was quashed, and its leaders, Talat Aydemir and Fethi Gürcan, were hanged. The resulting Aydemir Syndrome would help maintain the hierarchical unity of the military and thus reduce the fear of coup threats by renegade military elements. Together, the two syndromes constituted the boundaries of the Turkish state's power structure, and the nation's illiberal democratization process.

The compromise also marked the next stage in the progression from pendulum to an outright bifurcation in the state system (corresponding to section E in Figure 
1). With security demands providing the legitimization for statist elements, and liberalizing demands supporting the maintenance of a multiparty system, the need to find a manageable way to govern under these simultaneous pressures resulted in a compromise between two realms - a "hard" realm of security-minded elements and a political "soft" realm. The compromise also signalled acceptance of the idea that the democratic transformation could only be effectively and safely controlled by allowing the creation and consolidation of untouchable power centres, in other words, by a strong, autonomous inner state led by the Turkish military.

\section{Consolidation and institutionalization of reform security}

Over the next two decades, corresponding to the overall insecurity of the Cold War, internal clashes between the left and right, secularists and Islamists, and an increasingly violent Kurdish separatist movement in the south-east, the autonomy of the hard realm would become increasingly institutionalized, from the passing of laws giving the military strong powers over its own personnel, education, and financial resources, to the establishing of distinct military and civilian courts, and the introduction and expansion of the National Security Council (NSC). The 1982 constitution served to consolidate many of these security-based changes, and marked the peak period in the evolution of an established bifurcation in the Turkish state structure, in which the inner state, while maintaining some interaction with the government or "apparent" state (most dramatically through the platform of the NSC) was now virtually autonomous from government oversight and control. This period corresponds to section $\mathrm{F}$ in Figure 1.

The dual state structure reflected the Turkish national need to secure a gradual reform process from the risks and threats involved with liberalization and opening up. So long as the security demands - represented in Figure 1 by box A and by the examples for self-justification of the inner state (labelled "G", with examples of the Cold War, conflict with Greece and Iran, the Cyprus issue, and domestic struggles with Kurdish separatists and Islamists) - clearly seemed to outweigh those for reform - the ideologically appealing but less urgent demands represented by box B and by the examples for reform self-justification labelled " $\mathrm{H}$ " (Westernization) - the Turkish "inner state model" would remain to cope with both domestic and foreign policy.

But was that - or is that - as the stagnant democracy argument would suggest, the end of the story? Was Turkey's illiberal status permanent and static or would it ever be possible to talk about a deepening of political liberalization despite such a state structure?

\section{Towards reform-centric transformation and the democratic integrated state}

The primacy of security began to slowly change along with Turkey's accession process to the EU. At first the change was gradual, but it sped up dramatically in 
the first decade of the twenty-first century, and brought with it significant implications for Turkey's balancing of reform and security pressures. The early years of Turkey's EU accession process and overall relations with the Europeans can be described as a mutual pretense unaccompanied by substantive requirements from either side that allowed Turkish governance to maintain a security-centric balance. But the ever-growing demands of the liberalization process (both in terms of domestic expectations and in terms of EU stipulations such as meeting the Copenhagen Criteria) along with the gradual effects of established formal mechanisms of the EU accession process, came to mean that while Turkey was continuing to seek an "optimal balance" between two long-existing pressures, the understanding of "optimal" required a shift towards the reform side of the balance. Such a shift also required an evolution of the state structure to maintain that balance, moving towards an ideal of an integrated state structure (see Figure 2, section I) in which the inner state becomes subordinated to an overarching democratic "Turkish state".

Interestingly, the road to the EU and the resulting need to shift towards "reformcentric transformation" came to be seen as a strategic choice that was accepted not only by the political and business elite. For the leaders of the inner state, this route came to be viewed as the only possible strategy to respond to many domestic and external problems facing the country, from chronic economic problems, the possibility that Turkey might be left outside of the European security and defense structure, political Islam, and the Kurdish question. The only apparent alternative to the EU route appeared to be to face Turkey's problems alone, and that option clearly held the risk of utter failure or at best regressive reversals from the country's social, economic, and political progress. Thus, beginning around the time of the $1999 \mathrm{Hel}-$ sinki Summit, at which Turkey's eligibility for EU membership was certified, a new consensus between the inner and apparent states seems to have been reached on a commitment to the EU membership process, and with this, a need to readjust the balance towards reform rather than security. Having said that, the shift was not of course a black and white move from one perspective to another, and it was not without its complications.

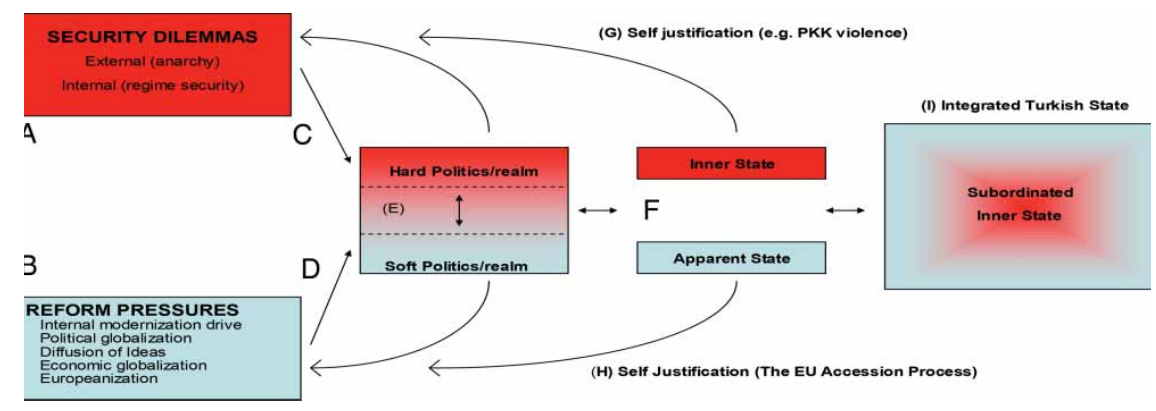

Figure 2. The Turkish model for reform security. 
The first major complications were expected to emerge when the 2002 parliamentary elections brought to power a government which, though broadly a conservative democratic party, also carried with it openly Islamist cultural values and overtones. ${ }^{37}$ In the past such parties had led to outright military coups as well as indirect ones (in the case of the 28 February 1997 easing from power of the Islamist prime minister). Surprisingly though, even under the political leadership of the moderate Islamist AK party government, the first several years of the consensus passed smoothly. For several reasons the government placed its full weight behind a reform-centric transformation, and its energies into the EU accession process. The government knew this route would clearly show that they were subscribing to mainstream politics rather than to marginal aspects of their broadly "Islamist" party. At the same time, by allying with the foreign forces (EU) their efforts would also strengthen them against the inner state. Even though the lack of confrontation between the AK party government and the military leadership of the inner state had much to do with the particular accommodative personality and beliefs of then Chief of Staff Hilmi Özkök, the larger reason was still the AK party's careful building up on the existing consensus, in the sense of not only concentrating on EU accession efforts, but also refraining from irritating inner state concerns, for example, pressing excessively for the headscarf issue, or for Kurdish rights.

By the start of 2006, there were some signs of the consensus shifting back towards a more security-centric balance. If we are to look for a starting point leading to such a shift, we might point to the EU's less than enthusiastic reactions to Turkey's revolutionary reforms and the Turkish public's increasing conviction that EU accession efforts were hopeless - the EU was beginning to reveal its seemingly subjective criteria to block Turkish membership, and was never going to accept Turkey into the union. Then, with Iraq sinking further into chaos and the Kurdistan Workers' Party (PKK) resuming violent action in Turkey, societal fear began to rise, and attention was turned again to society's own faultlines - political Islam and the possible hidden agendas of the AK party government, the separatist movement in the south-east and its connections with the rising Kurdish state in northern Iraq. As had been the general tendency in past decades, the degree of national insecurity - and subsequently the securitization of daily life and politics - became widespread, culminating with the tensions over the presidential selection process of 2007, and the army's website warning, or "e-coup attempt" - a sign of the inner state reminding everyone that it remained on guard as the ultimate response to a national fear of collapse.

Ultimately however, even that tense period amounted to nothing, and President Gül took his place in the presidential palace. When the majority AK party government then went on to tackle that most challenging of issues - reversing the constitutional law that forbids female students from wearing headscarves on university grounds - again, the army remained quiet. Arguably, even though the army was naturally opposed to this move, they were unwilling to "look like the bad guy"38 in the eyes of society, and were therefore waiting for the civilian legal process to 
unfold; waiting to see whether the Constitutional Court would confirm parliament's vote. Subsequent behaviour, such as the military's failure to resist the arrests of army figures accused of coup plotting in the ongoing Ergenekon scandal, and a former chief of staff's open statement to the media that the army has a proper channel to communicate its ideas (the NSC) and should restrict itself to that channel, are signs of self-restraint and of a reluctance to intervene in politics.

This reluctance to intervene shows how the Turkish inner state has learned, over years of back and forth, that military interventions into daily politics, while producing short-term achievements of pushing back "radical" ideologies, have ultimately led to comebacks by the "victims". This was the case in 1965, 1983, 2002, and 2007. Perhaps because of this, while the Islamists have softened their discourse, military interventions (not always in response only to political Islamist concerns) have also become less direct. From a coup in which the elected leaders were hanged (1960), to one in which the prime minister and leaders were jailed and kicked out of politics (1980), to a post-modern coup (1997) in which a couple of tanks and the media were used to prepare the public and the NSC was used to force the resignation of the prime minister, to 2007, a quiet Friday night posting to a website leading the prime minister to back away from his candidate and call for early parliamentary elections. The Turkish inner state seems to have learned that society could eventually turn against them if they come out too strongly against societal values - one of which may even be democracy itself - but more importantly there are signs that the Turkish inner state is not a completely monolithic, isolated, and unchanging entity that has remained untouched by years of back and forth. New thinking is now on record even within parts of the army that the military should be kept subordinate to politics, ${ }^{39}$ and that there is in fact a clear decrease in the weight of those who would like to preserve a security-centric transformation and others who lean towards reform-centric transformation.

\section{Who controls securitization?}

Which brings us once again back to the question of whether Turkey is a permanent imperfect democracy. Has the "pulling and hauling" within the Turkish governance system led to a consolidated reform-centric balance in which there is enough selfconfidence to push aside the guarantor of the inner state once and for all? Is there enough confidence that the nation can, through politics, reign in its marginal elements - be they religious, ethnic, or other - and safely complete the liberalization process? For a country working through the reform/security dilemma, the ultimate sign of whether the reform side has truly established its dominant position may very well be when the leaders of the reform process, the politicians of the apparent state, assume the management of responsibilities traditionally belonging to the security realm - defining what constitutes national threats, determining what should be done to counter those threats, and organizing the responses to them. 
In other words, assuming a democratic control over the very securitization process that, in such an insecure environment, traditionally allows the security sector to take a predominant role.

There seems to be one problematic issue left in Turkey with the potential of raising widespread societal fear, of being thus open to easy securitization, and capable of bringing the inner state's role once again to the forefront - which would indicate that the inner state is indeed a permanent aspect of Turkish governance and that Turkish society is stuck in a vicious circle of illiberal democracy. This is the Kurdish separatist question - how it should be managed and by whom. If there is any indication at this stage of Turkey's liberalization journey that the traditional securitization tendency of the Kurdish question by the inner state is being blocked, reversed, or desecuritized by the soft realm of politics, then it is possible to begin speaking of a sea change, a true shrinking of the country's authoritarian tendencies, and a breaking away from its illiberal status.

Early, cautiously optimistic signs emerged both with the 2007 and 2011 parliamentary elections. Those elections suggest that a majority of the nation has decided to trust in politics as the ultimate tool to manage even this most deeply embedded of their divisions and fears. In the majority Kurdish populated regions of the country, the self-defined political centrist AK party government has generally been able to win over at least as many votes as the openly pro-Kurdish candidates. At the same time, in regions in which openly anti-Kurdish sentiment and the Turkish nationalist Milliyetci Hareket Partisi have traditionally been strongest, again the political centrist AK government consistently seems able to win the vast majority. In other words, even in the most polarized regions of the country with respect to separatism, a majority of the public is ready to opt for a centrist route rather than the more radical choices on either side.

In the years between these two elections, the government seemed equally willing to put itself on the line in order to show that politics and politicians are capable of handling even this major security issue. When post-election PKK violence broke out in 2008 and a number of soldiers were killed, the government resisted domestic calls for a powerful military response. True, they passed a resolution in parliament giving the government authority to allow military operations into northern Iraq, but they did not immediately call for such moves - despite the chief of staff's assertion that they were necessary. They instead insisted that it was the government's and politicians' jobs to determine when the time was right, and repeatedly made the argument that even though the military option was on the table, political, economic, and diplomatic options should be prioritized. Though some military moves were eventually employed, at the end, the government's efforts can be argued to have been part of the producing of a new type of environment, one in which a traditional, military option has become just one instrument of an overall political offensive against security problems. In the discussion, the government displayed that it could act in a professional manner, cultivating the support of opinion leaders such as the media, intellectuals, and think tanks and showing that the soft realm has not only expanded but has within it the figures, 
institutions, and coordination capacity to take on complex security issues and reconstruct them in a more civilian perspective.

In the lead-up to the 2011 elections, there was continued cautiously optimistic evidence of the "politicizing" of this security issue. Among leading political party leaders the Kurdish question has become a topic for debate, with the main opposition Republican People's Party (CHP) leader raising the possibility of Turkey accepting a "European standard" of autonomy. While it remains still very much an unresolved issue, at minimum, the politicians seem to be the ones in the driver's seat, and seem to be trying to manage it within the democratic system. Realistically though, it must be acknowledged that the continued strong presence of a separatist/nationalist movement in the country still carries the definite potential of substantively disrupting Turkey's liberalization process. How Turkey turns this last corner in its historical evolution into a liberal democracy and copes with the Kurdish question might also carry a demonstrative impact for other Middle Eastern states dealing with their own fragmented societal fabrics and individual reform/security dilemmas.

\section{Conclusion}

Making the transformation to a liberal democratic state structure from an authoritative one is a complex task for any nation. The task becomes even more complex when the country attempting it is subject to internal and external anarchic pressures. Recognizing the need to strike a proper balance between security and reform, understanding the evolution of these two components in a manner that allows for defining that "proper" balance, and creating effective institutions and agents to maintain a safe and secure reform process, are essential acts for such a nation. Failure to achieve a workable reform security can provoke regressive societal divisions and fears, and progressive instincts for reform will likely be sacrificed to those fears. Societies which feel they are risking their very existence will not be willing to proceed into uncharted and turbulent practices of liberalization, and societies that do not have the chance to practice and experience liberal values will have a very difficult time becoming full liberal democracies.

What insights can the Turkish case have for other countries seeking secure regime reform or for countries deciding whether or how to pursue policies of democracy promotion around the world? The overall Turkish case, not the Turkey of 1960, or 1980, or even 1997, but Turkey's more than 50 years of dynamic illiberal democratization, shows that a gradual retreat of the inner state is possible, and that the reform/security dilemma need not conclude in an either/ or endpoint. This is shown in the evidence of civilian politicians beginning to gain control over the securitization process, and this is shown in the inability and perhaps even unwillingness of the authoritarian power centres to prevent them from doing so. Throughout the give-and-take learning process that has characterized Turkey's political liberalization, the Turkish inner state has itself had to become accountable, perhaps not on paper, but in terms of its legitimacy 
in societal opinion. The core of the inner state, the Turkish army, has learned that without societal support, they lose status, prestige, and legitimacy, and thus it would be prudent to consider societal opinion before making a move into the governance realm. This exemplifies an acceptance, however grudging, of a liberal value - accountability - at the core of an illiberal power centre.

What does this mean for modern sceptics of the transition paradigm, or for those who would shy away from ever supporting non-democratic forces while trying to promote democracy? It shows us that in countries facing both security concerns and a need to still transform into liberal democracies, a collective demand for a safe and stable transformation might very well lead to the formation of inner statehoods. The desire for stable transformations leads to Russian society's support of Vladimir Putin's hardline politics after an era of Yeltsin's uncontrolled and chaotic liberalization, and can also help explain significant Iranian public support for politicians like Ahmadinejad after an unstable period of reformist politics. It also may explain the powerful role of the intelligence bureaucracy (ISI) in Pakistan, and that of the Turkish military. None of these examples is accidental; all reflect an underlying dynamic of competing pressures for reform and security.

Naturally though, the question arises: how do you prevent the supposed guarantor from succumbing to its presumable natural tendencies and preying on the reform itself in the name of security? Three things seem to be essential, at the institutional, national, and international levels. First, at the institutional level, some degree of autonomy of the security projector may be acceptable, as long as the institution's underlying philosophy contains basic beliefs for modernity and progress - even if these remain only a long-term goal. Overt goals of democratization for such institutions may be unrealistic, but modernization at least is essential. It will be difficult for those who have been indoctrinated in such a modernizing philosophy to fully deny at least some degree of democratic practices.

Second, at the national level, the successful guarantor must be capable of legitimately projecting a sense of safety to a majority of the actors of the transformation, for example, all segments of the society, the business and bureaucratic elite. To manage this, the security projector must not be exclusively attached to any one ethnicity, ideology, or class. In the Turkish case for example, the Turkish military has not been openly dominated by any one group, and has drawn from most segments of society without overt discrimination. Ironically, the autonomy that has justifiably made the military a target of criticism has also helped it remain relatively unpenetrated by societal faultlines, ideological divisions, mass movements, and so on. This, in turn, has facilitated its high-ranking national popularity and image, and allowed it to provide the necessary image of broad security projector.

Finally, this guarantor must not be cut off from the international community. Indeed, whether of its own volition or with the encouragement of outside forces, its links with the outside world must be strengthened and institutionalized, in order to keep the guarantor progressive and exposed to broader liberal ideas and practices. Since the guarantor is generally a security force of some kind, such links may include arranging international trainings or exercises, encouraging 
membership in international institutions or organizations, sponsoring exchanges of personnel, and so on. Linked to this idea of building channels, the guarantor must not be dismissed as a player in the transformation and reform process, but rather brought into and made a part of it.

When it comes to so-called democracies with adjectives and those countries of the "Arab Spring" that may one day be given this label, Turkey reminds us that liberalization is a dynamic process, and that evidence of authoritarian persistence does not necessarily rule out the possibility of democratic change - even for adopting liberal democratic values - if those authoritarian tendencies are allowing some kind of repeated practice of democratic principles. Being liberal is not limited to those born into it or those who quickly adopt it. Liberalness can also be the result of a constructed process of hard work and practice, throughout which both authoritarian figures and politicians gradually learn to postpone shortsighted interests (for example, quick popularity) for long-term ones. Learning to be liberal requires practice, a chance for all sides to reposition themselves over time, to come to tolerate others' positions, and ultimately to meet at a liberal endpoint. In many cases, the key to success may be to find a mechanism that can comfort all sides' basic fears, allow a chance for repeated practice, to allow time to learn to become liberal. Turkey is not an exception in terms of its apparent success in overcoming the reform/security dilemma, it has just been working at it much longer than most countries. Turks have been learning under difficult conditions, suggesting that every country may have a viable chance. Today's countries in transition, even those in which authoritarian elements linger, also have a chance to become liberal governance systems some day, and for now it would be unfair to look at the nature of their current stage of transformation and brand them with eternal illiberalness.

\section{Notes}

1. President Bush (1 August 2008), President Obama speaking to the Turkish Parliament (4 June 2009).

2. Harvey, Viscusi, and Darhally, "Arabs Battling Repression"; Martin, "Turkey can Model Democracy"; National Public Radio, "Turkish Democracy."

3. Cagaptay, "Sultans of the Muslim World"; Kinzer, "Turkey Leads the Muslim World"; Walker, "A Fellow's View"; Tait, "Egypt" For more scholarly perspectives on Turkey's potential role as model see Kirisci, "Turkey's 'Demonstrative Effect"”; and Hinnebusch, "Toward a Historical Sociology."

4. Pope, Speaking on NPR; Karakas, "Can Turkey be an 'Inspiration'?" Other negative views towards the idea of Turkey as a model stem from arguments that Turkey is itself too flawed to serve as one, for example, Tepe, "Turkey's AKP"; Secor, "Turkey's Democracy."

5. See for example, ANSAmed, "Uprisings."

6. Suttner, "Democratic Transition and Consolidation in South Africa"; El-Mahdi, "Enough!"; Volpi and Cavatorta, "Forgetting Democratization?"; Croissant, "From Transition to Defective Democracy"; Hadiz, "Reorganizing Political Power in Indonesia"; Hasim, "Putin's Etatization Project"; Im, "Faltering Democratic Consolidation in 
South Korea"; Lee, "Democratic Transition and the Consolidation of Democracy"; Solnick, "Russia's 'Transition."

7. Diamond, "Thinking about Hybrid Regimes"; Ekman, "Political Participation and Regime Stability"; Jayasuriya and Rodan, "Beyond Hybrid Regimes"; Levitsky and Way, Competitive Authoritarianism; Morlino, "Hybrid Regimes or Regimes in Transition?"

8. Albritton, "Thailand in 2005"; Case, "Malaysia's General Elections"; Freedman, "Consolidation or Withering Away?"; Ganesan, "Appraising Democratic Consolidation"; Pathmanand, "A Different Coup d'Etat?"

9. Zakaria, "The Rise of Illiberal Democracy"; Zakaria, The Future of Freedom.

10. Furman, "The Origins and Elements of Imitation Democracies."

11. Volpi, "Algeria's Pseudo-Democratic Politics."

12. Diamond, Developing Democracy.

13. Haleem, "Ethnic and Sectarian Violence."

14. Goldberg, "The Growing Militarization"; Kamrava, "Military Professionalization"; Salt, "Turkey's Military Democracy."

15. Jurgeleviciute, "Russia's Ideational 'Democratization'."

16. Collier and Levitsky, "Democracy with Adjectives"; Levitsky and Way, "The Rise of Competitive Authoritarianism."

17. Carothers, "The End of the Transition Paradigm."

18. It has been pointed out that in the Middle East fears of governmental opening up extend even to the middle classes and intelligentsia who are commonly the strongest supporters of such change. Hinnebusch, "Authoritarian Persistence."

19. O'Donnell and Schmitter, Transitions from Authoritarian Rule, 16.

20. Lee, "The Armed Forces and Transitions from Authoritarian Rule."

21. Schmitter, "Twenty-five Years, Fifteen Findings."

22. Kuok, "Security First."

23. Fukuyama and McFaul, "Should Democracy be Promoted?"

24. Bogaards, "Measuring Democracy."

25. Lindberg and Clark, "Does Democratization Reduce the Role of Military Interventions?"

26. Brown and Kaiser, "Democratisations in Africa."

27. Cook, "Getting to Arab Democracy."

28. Security demands are understood here as stemming from not only external threats but also internal ones, most significantly those posed by the separatist Kurdish PKK and the overall threat from political Islam to the secularist regime.

29. Cizre, "The Anatomy of the Turkish Military's Political Economy"; Cizre, "Demythologyzing the National Security Concept"; Demirel, "Soldiers and Civilians"; Heper and Guney, "The Military and the Consolidation of Democracy"; Karaosmanoglu, "The Evolution of the National Security Culture"; Rouleau, "Turkey's Dreams"; Sarigil, "Europeanization as Institutional Change"; Yavuz, "Turkey's Imagined Enemies."

30. BBC, "Turkish Military's Role in Politics as Institutional Change"; Jonathan Mann, CNN, http://transcripts.cnn.com/TRANSCRIPTS/0704/13/ywt.01.html.

31. A group of retired army officers who were caught taking an oath to take up arms against "state enemies." For more on the shadier sides of the Turkish "deep" state, see Kavakci, "Turkey's Test with its Deep State."

32. Cizre, "Politics and Military"; Heper, The State Tradition; Heper and Evin, State, Democracy and the Military; Jenkins, Context and Circumstance; Ozbudun, Contemporary Turkish Politics.

33. For example, Gursoy, "The Impact of EU-Driven Reforms"; Lim, "The Paradox of Turkish Civil-Military Relations." 
34. Exceptions include Heper, "The Justice and Development Party Government"; Karaosmanoglu, "Sivil-Asker Iliskiler."

35. Barlas, Etatism and Diplomacy; Dagi, "Democratic Transition"; Insel, "TSK'nin Konumunu"; Somer, "Resurgence and Remaking"; Sunar and Sayari, "Democracy in Turkey."

36. Cagatay, Türkiye'de Gerici Eylemler.

37. The AK party from the start distanced itself from any "Islamist" labelling, preferring the term "conservative democrats." For a thorough overview of the AK party's positioning and rhetoric, see Yavuz, Secularism and Muslim Democracy in Turkey.

38. This assertion comes from a retired army officer, speaking at the time on condition of anonymity.

39. Başbuğ, speech transcript, Turkish General Staff, http://www.tsk.tr/.

\section{Notes on contributor}

Dr Ersel Aydinli is an associate professor in the Department of International Relations at Bilkent University in Ankara. His current research interests focus on non-state security actors and transnational relations, homegrown IR theorizing and Turkish politics and foreign policy. His latest book is Violent Non-State Actors: From Anarchists to Jihadists (Routledge, forthcoming 2013).

\section{Bibliography}

Albritton, Robert B. "Thailand in 2005: The Struggle for Democratic Consolidation." Asian Survey 46, no. 1 (2006): 140-147.

ANSAmed. "Uprisings: Turkey, the New Political Model for Islamic World." Accessed February 8, 2012. http://www.ansamed.info/en/emirati/news/ME.XEF70804.html

Barlas, Dilek. Etatism and Diplomacy in Turkey: Economic and Foreign Policy Strategies in an Uncertain World, 1929-1939. Leiden: Brill, 1989.

Başbuğ, İlker. Speech Transcript. Accessed February 8, 2012. Turkish General Staff. http:// www.tsk.tr/

BBC. "Turkish Military's Role in Politics.” Accessed February 8, 2012. http://news.bbc.co. uk/2/hi/europe/904758.stm

Bogaards, M. "Measuring Democracy through Election Outcomes: A Critique with African Data." Comparative Political Studies 40, no. 10 (2007): 1211-1237.

Brown, Steven, and Paul Kaiser. "Democratisations in Africa: Attempts, Hindrances and Prospects." Third World Quarterly 28, no. 6 (2007): 1131-1149.

Cagaptay, Soner. "Sultans of the Muslim World: Why the AKP's Turkey will be the East's Next Leader." Foreign Affairs, November 15, 2010. http://www.foreignaffairs.com/ articles/67009/soner-cagaptay/sultan-of-the-muslim-world

Cagatay, Neset. Türkiye'de Gerici Eylemler: 1923ten bu Yana [Regressive Activities in Turkey: From 1923 until Today], Ankara: Ankara Üniversitesi Yayınları, 1972.

Carothers, Thomas. "The End of the Transition Paradigm." Journal of Democracy 13, no. 1 (2002): 5-20.

Case, William. "Malaysia's General Elections in 1999: A Consolidated and High-Quality Semi-Democracy." Asian Studies Review 25, no. 1 (2001): 35-56.

Cizre, Umit. "The Anatomy of the Turkish Military's Political Autonomy." Comparative Politics 29, no. 2 (1997): 151-166.

Cizre, Umit. "Demythologyzing the National Security Concept: The Case of Turkey." Middle East Journal 57, no. 2 (2003): 213-224. 
Cizre, Umit. "Politics and Military into the 21st Century." EUI Working Papers RSC No. 2000/24. European University Institute, San Domenico, 2006.

Collier, David, and Steven Levitsky. "Democracy with Adjectives: Conceptual Innovation in Comparative Research." World Politics 49, no. 3 (1997): 430-451.

Cook, Steven. "Getting to Arab Democracy: The Promise of Pacts." Journal of Democracy 17, no. 1 (2006): 63-74.

Croissant, Aurel. "From Transition to Defective Democracy: Mapping Asian Democratization." Democratization 11, no. 5 (2004): 156-178.

Dagi, Ihsan. "Democratic Transition in Turkey: The Impact of European Diplomacy." Middle Eastern Studies 32, no. 2 (1996): 124-141.

Demirel, Tanel. "Soldiers and Civilians: The Dilemma of Turkish Democracy." Middle Eastern Studies 40, no. 1 (2004): 127-150.

Diamond, Larry. Developing Democracy: Toward Consolidation. Baltimore, MD: Johns Hopkins University Press, 1999.

Diamond, Larry. "Thinking About Hybrid Regimes." Journal of Democracy 13, no. 2 (2002): $21-35$.

Ekman, Joakim. "Political Participation and Regime Stability: A Framework for Analyzing Hybrid Regimes." International Political Science Review 30, no. 1 (2009): 7-31.

El-Mahdi, R. "Enough! Egypt's Quest for Democracy." Comparative Political Studies 42, no. 8 (2009): 1011-1039.

Freedman, Amy L. "Consolidation or Withering Away of Democracy? Political Changes in Thailand and Indonesia." Asian Affairs: An American Review 33, no. 4 (2007): 195-216.

Fukuyama, Francis, and Michael McFaul. "Should Democracy be Promoted or Demoted?" Washington Quarterly 31, no. 1 (2007/08): 23-45.

Furman, Dmitri. "The Origins and Elements of Imitation Democracies: Political Developments in the Post-Soviet Space." Osteuropa: The Europe beyond Europe Autumn (2007): 205-244.

Ganesan, N. "Appraising Democratic Consolidation in Thailand Under Thaksin's Thai Rak Thai Government.” Japanese Journal of Political Science 7, no. 2 (2006): 153-174.

Goldberg, Giora. "The Growing Militarization of the Israeli Political System." Israel Affairs 12, no. 3 (2006): 377-394.

Gursoy, Yaprak. "The Impact of EU-Driven Reforms on the Political Autonomy of the Turkish Military.” South European Society \& Politics 16, no. 2 (2011): 293-308.

Hadiz, Vedi. "Reorganizing Political Power in Indonesia: A Reconsideration of So-Called 'Democratic Transitions'.” Pacific Review 16, no. 4 (2003): 591-611.

Haleem, Irm. "Ethnic and Sectarian Violence and the Propensity Towards Praetorianism in Pakistan." Third World Quarterly 24, no. 3 (2003): 463-477.

Harvey, Benjamin, Gregory Viscusi, and Massoud Darhally. "Arabs Battling Repression see Erdogan's Muslim Democracy as Model.” Bloomberg News, February 4, 2011. http://www.bloomberg.com/news/2011-02-04/arabs-battling-regimes-see-erdogan-smuslim-democracy-in-turkey-as-model.html

Hasim, S. Mohsin. "Putin's Etatization Project and Limits to Democratic Reforms in Russia." Communist and Post-Communist Studies 38, no. 1 (2005): 25-48.

Heper, Metin. The State Tradition in Turkey. Northgate: Eothen Press, 1985.

Heper, Metin. "The Justice and Development Party Government and the Military." Turkish Studies 6, no. 2 (2005): 215-231.

Heper, Metin, and Ahmet Evin, eds. State, Democracy and the Military in the 1980s. Berlin: Walter de Gruyter, 1988.

Heper, Metin, and Aylin Guney. "The Military and the Consolidation of Democracy: The Recent Turkish Experience.” Armed Forces and Society 26, no. 4 (2000): 635-657.

Hinnebusch, Raymond. "Authoritarian Persistence, Democratization Theory and the Middle East: An Overview and Critique.” Democratization 13, no. 3 (2006): 373-395. 
Hinnebusch, Raymond. "Toward a Historical Sociology of State Formation in the Middle East." Middle East Critique 19, no. 3 (2010): 201-216.

Im, H. B. "Faltering Democratic Consolidation in South Korea: Democracy at the End of the 'Three Kims' Era." Democratization 11, no. 5 (2004): 179-198.

Insel, Ahmet. “TSK'nin Konumunu Degerlendirmek.” Birikim 160/161 (2002): 18-27.

Jayasuriya, Kanishka, and Garry Rodan. "Beyond Hybrid Regimes: More Participation, Less Contestation in Southeast Asia.” Democratization 14, no. 5 (2007): 773-794.

Jenkins, Gareth. Context and Circumstance: The Turkish Military and Politics. The International Institute for Strategic Studies, Adelphi Paper 337. New York: Oxford University Press, 2001.

Jurgeleviciute, D. 'Russia's Ideational 'Democratization' Through the Idea of 'Sovereign Democracy." Paper presented at the Millennium Journal of International Studies annual conference, London, October 25-26, 2008.

Kamrava, Mehran. "Military Professionalization and Civil-Military Relations in the Middle East." Political Science Quarterly 115, no. 1 (2000): 67-92.

Karakas, Cemal. "Can Turkey be an 'Inspiration' for Other Muslim Countries? The 'Kemalist Trinity' of Republicanism, Nationalism, and Secularism, and the Prospects of Turkish EU Membership." Paper presented at the 7th Pan-European international relations conference of the Standing Group on International Relations (SGIR) of the ECPR, Stockholm, 2010.

Karaosmanoglu, Ali. "The Evolution of the National Security Culture and the Military in Turkey." Journal of International Affairs 54, no. 1 (2000): 199-217.

Karaosmanoglu, Ali. "Sivil-Asker Iliskileri Uzerine bir Kritik." [A Critique of CivilMilitary Relations], Zaman, February 7, 2007. http://www.zaman.com.tr/haber.do? haberno=498353\&title=yorum-profdrali-lkaraosmanoglu-sivilasker-iliskileri-uzerinebir-kritik\&haberSayfa $=1$

Kavakci, Merve. "Turkey's Test with its Deep State." Mediterranean Quarterly 24, no. 4 (2004): 83-97.

Kinzer, Stephen. "Turkey Leads the Muslim World.” The Guardian, October 27, 2009. http:// www.guardian.co.uk/commentisfree/2009/oct/27/turkey-muslim-world-leader-israel

Kirisci, Kemal. "Turkey's 'Demonstrative Effect' and the Transformation of the Middle East.” Insight Turkey 13, no. 2 (2011): 33-55.

Kuok, Lynn. "Security First: The Lodestar for U.S. Foreign Policy in Southeast Asia?" American Behavioral Scientist 51, no. 9 (2008): 1405-1450.

Lee, Sangmook. "Democratic Transition and the Consolidation of Democracy in South Korea." Taiwan Journal of Democracy 3, no. 1 (2007): 99-125.

Lee, Terence. "The Armed Forces and Transitions from Authoritarian Rule: Explaining the Role of the Military in 1986 Philippines and 1998 Indonesia." Comparative Political Studies 42, no. 5 (2009): 640-669.

Levitsky, Steven, and Lucan A. Way. "The Rise of Competitive Authoritarianism." Journal of Democracy 13, no. 2 (2002): 51-65.

Levitsky, Steven, and Lucan A. Way. Competitive Authoritarianism: The Emergence and Dynamics of Hybrid Regimes in the Post-Cold War Era. New York: Cambridge University Press, 2009.

Lim, Richard M. "The Paradox of Turkish Civil Military Relations." Journal of Applied Security Research 6, no. 2 (2011): 255-272.

Lindberg, Staffen I., and John F. Clark. "Does Democratization Reduce the Role of Military Interventions in Africa?" Democratization 15, no. 1 (2008): 86-105.

Mann, Jonathan. CNN. http://transcripts.cnn.com/TRANSCRIPTS/0704/13/ywt.01.html

Martin, Frankie. "Turkey can Model Democracy for the Arab World." CNN Opinion, February 16, 2011. http://articles.cnn.com/2011-02-16/opinion/martin.egypt.turkey_ 1_islam-and-democracy-rachid-ghannouchi-turkey?_s=PM:OPINION 
Morlino, Leonardo. “Hybrid Regimes or Regimes in Transition?” FRIDE Working Paper 70, 2008.

National Public Radio. "Turkish Democracy: A Model for Other Countries?" April 14, 2011. http://www.npr.org/2011/04/14/135407687/turkish-democracy-a-model-forother-countries

O'Donnell, Guillermo, and Phillipe Schmitter. Transitions from Authoritarian Rule: Tentative Conclusions about Uncertain Democracies. Baltimore, MD: Johns Hopkins University Press, 1986.

Ozbudun, Ergun. Contemporary Turkish Politics: Challenges to Democratic Consolidation. Boulder, CO: Lynne Rienner, 2000.

Pathmanand, Ukrist. "A Different Coup d'Etat?" Journal of Contemporary Asia 38, no. 1 (2008): 124-142.

Pope, Hugh. Speaking on National Public Radio. Accessed February 8, 2012. http://www. npr.org/2011/04/14/135407687/turkish-democracy-a-model-for-other-countries

Rouleau, Eric. "Turkey's Dreams of Democracy.” Foreign Affairs 79, no. 6 (2000): 100-114.

Salt, Jeremy. "Turkey's Military Democracy." Current History 98, no. 625 (1999): 72-78.

Sarigil, Zeki. "Europeanization as Institutional Change: The Case of the Turkish Military." Mediterranean Politics 12, no. 1 (2007): 39-57.

Schmitter, Philippe C. "Twenty-five Years, Fifteen Findings." Journal of Democracy 21, no. 1 (2010): 17-28.

Secor, Anna. "Turkey's Democracy: A Model for the Troubled Middle East?" Eurasian Geography and Economics 52, no. 2 (2011): 157-172.

Solnick, Steven L. "Russia's 'Transition': Is Democracy Delayed Democracy Denied?" Social Research 66, no. 3 (1999): 789-824.

Somer, M. "Resurgence and Remaking of Identity: Civil Beliefs, Democratic and External Dynamics, and the Turkish Mainstream Discourse on Kurds." Comparative Political Studies 38, no. 6 (2005): 591-622.

Sunar, Ilkay, and Sabri Sayari. "Democracy in Turkey: Problems and Prospects." In Transitions from Authoritarian Rule: Southern Europe, edited by Guillermo O'Donnell, Phillippe C. Schmitter and Laurence Whitehead 165-186, Baltimore, MD: The Johns Hopkins University Press, 1986.

Suttner, Raymond. "Democratic Transition and Consolidation in South Africa: The Advice of 'the Experts'." Current Sociology 52 (2004): 755-773.

Tait, Robert. "Egypt: Doubts Cast on Turkish Claims for Model Democracy." The Guardian, February 13, 2011. http://www.guardian.co.uk/world/2011/feb/13/egypt-doubt-turkishmodel-democracy

Tepe, Sultan. “Turkey's AKP: A Model 'Muslim Democratic' Party?" Journal of Democracy 16, no. 3 (2005): 69-82.

Volpi, Frederic. "Algeria's Pseudo-Democratic Politics: Lessons for Democratization in the Middle East." Democratization 13, no. 3 (2006): 442-455.

Volpi, Frederic, and Francesco Cavatorta. "Forgetting Democratization? Recasting Power and Authority in a Plural Muslim World." Democratization 13, no. 3 (2006): 363-372.

Walker, Joshua W. “A Fellow's View: Inshallah, a Middle East like Turkey not Iran.” Belfer Center Newsletter, Harvard University, Summer, 2011.

Yavuz, Hakan. "Turkey's Imagined Enemies: Kurds and the Islamists." World Today 52, no. 4 (1996): 99-104.

Yavuz, Hakan. Secularism and Muslim Democracy in Turkey. Cambridge, UK: Cambridge University Press, 2009.

Zakaria, Fareed. "The Rise of Illiberal Democracy." Foreign Affairs 76, no. 6 (1997): 22-43.

Zakaria, Fareed. The Future of Freedom: Illiberal Democracy at Home and Abroad. New York: W. W. Norton \& Co, 2003. 